НАУКОВИЙ ВІСНИК

Sientific messenger of Lviv National University

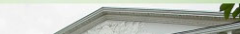

(1)

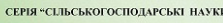

Том 22 № 93

2020
Науковий вісник Дьвівського національного університету ветеринарної медицини та біотехнологій імені С.3. Гжицького. Серія: Сільськогосподарські науки

Scientific Messenger of Lviv National University of Veterinary Medicine and Biotechnologies. Series: Agricultural sciences

\title{
Influence of mixed-liganding complexes of Zinc, Manganese and Cobalt in feeding highly productive cows in the early dry period for their dairy productivity in the first $\mathbf{1 0 0}$ days of lactation and reproductive functions
}

\author{
Yu. G. Kropyvka ${ }^{1}$, V. S. Bomko² \\ ${ }^{1}$ Stepan Gzhytskyi National University of Veterinary Medicine and Biotechnologies, Lviv, Ukraine \\ ${ }^{2}$ Bila Tserkva National Agrarian University, Bila Tserkva, Kyiv region, Ukraine
}

Article info

Received 14.09.2020

Received in revised form 14.10.2020

Accepted 15.10.2020

Stepan Gzhytskyi National University of Veterinary Medicine and Biotechnologies Lviv, Pekarska Str., 50, Lviv, 79010, Ukraine.

Tel.: +38-097-431-88-30 E-mail: sy-kropuvka@ukr.net

Bila Tserkva National Agrarian University, pl. 8/1 Soborna, Bila Tserkva, 09117, Ukraine.
Kropyvka, Yu. G., \& Bomko, V.S. (2020). Influence of mixed-liganding complexes of zinc, manganese and cobalt in feeding highly productive cows in the early dry period for their dairy productivity in the first 100 days of lactation and reproductive functions. Scientific Messenger of Lviv National University of Veterinary Medicine and Biotechnologies. Series: Agricultural sciences, 22(93), 132 136. doi: $10.32718 /$ nvlvet-a9322

A number of scientific publications on the influence of microelements on the vital activity of cows, the level of milk productivity and reproductive function are analyzed. The article presents the results of research on the study of different levels of mixed-ligand complexes of Zinc, Manganese and Cobalt in the feeding of cows in the dry season for their future milk productivity and reproductive functions. The research was carried out in the conditions of "Terezine", Bila Tserkva district, Kyiv region, on highly productive cows of the Ukrainian black-spotted dairy breed. It was found that the elimination of Zinc, Manganese and Cobalt deficiency in the diets of cows in the dry season due to different doses of their mixed-ligand complexes had a positive effect on further milk productivity. In terms of gross milk yield of natural milk for milk of $4 \%$ fat content, the difference in this indicator between the cows of the 2nd experimental group and control was $195.9 \mathrm{~kg}$, or $5.52 \%(P<0.01)$, the $3 \mathrm{rd}$ experimental $-220.4 \mathrm{~kg}$, or $6.21 \%(P<0.001)$, the 4 th experimental $-242.0 \mathrm{~kg}$, or $6.82 \%(P<0.001)$ and the 5th experimental group and control $-116.3 \mathrm{~kg}$, or $3.28 \%$. Different concentrations of mixed-ligand complexes of the studied micronutrients in the diets of dry and lactating cows differently affected their reproductive functions. One fertile insemination of each cow in the 1st control group required 2.8 inseminations, in the $2 \mathrm{nd}$, $3 \mathrm{rd}$, 4th and 5th experimental groups - 2.1; 1.9; 1.7 and 2.3 fertilization, which is 75.0 according to the control; 67.9; 60.7 and 82.1\%. Lower levels of Zinc, Manganese and Cobalt led to positive dynamics in the physiological state of cows, stimulated their hunting and provided normal conditions for the processes of fertilization and embryo development in cows. The best effect on the milk productivity of cows and their reproductive functions had the following levels of trace elements in $1 \mathrm{~kg}$ of SR feed, mg: Zinc - 30; Manganese - 30; Cobalt - 0.38; Selenium - 0.3; Copper 9 and Iodine - 0.7. This concentration of trace elements was achieved due to their mixed-ligand complexes, and Copper - its sulfate, Iodine - potassium iodide, and Selenium - selenium Suplex.

Key words: highly productive cows, milk productivity, reproductive function, microelements, mixedligand complex.

\section{Вплив змішанолігандних комплексів Цинку, Мангану й Кобальту в годівлі високопродуктивних корів у ранній сухостійний період на їх молочну дуктивність в перші 100 днів лактації та відтворні функції}

\author{
Ю. Г. Кропивка ${ }^{1}$ В. С. Бомко ${ }^{2}$
} IЛьвівський наџіональний університет ветеринарної медиџини та біотехнологій імені С. 3. Гжиџького, м. Львів,
Украйна 


\section{${ }^{2}$ Білочерківський національний аграрний університет, м. Біла Церква, Київська область, Украӥна}

Проаналізовано ряд наукових публікацій щзоо впливу мікроелементів на життєдіяльність організму корів, рівень молочної продуктивності і відтворної функиіі. У статті представлені результати досліджень по вивченню різних рівнів змішанолігандних комплексів Цинку, Мангану і Кобальту в годівлі корів у сухостійний період на їх майбутню молочну продуктивність та відтворні функиіі. Дослідження проводилися в умовах ТОВ “Терезіне” Білоцерківського району Київскої області на високопродуктивних коровах украӥнської чорно-рябої молочної породи. Встановлено, щуо ліквідація дефіциту Цинку, Мангану й Кобальту в раціонах корів у сухостійний період за рахунок різних доз їх змішанолігандних комплексів позитивно вплинула на подальшу молочну продуктивність. У перерахунку валового надою натурального молока на молоко 4 \%-ї жирності різниця за циим показником між коровами 2-ї дослідної групи й контролем склала 195,9 ка, або 5,52\% (P < 0,01), 3-ї дослідної- 220,4 кг, або 6,21 \% (P< 0,001), 4-ї дослідної242,0 кг, або 6,82 \% (P < 0,001) і 5-ї дослідної групи й контролем - 116,3 к2, або 3,28\%. Різні концентрації змішанолігандних комплексів досліджуваних мікроелементів в раціонах сухостійних і лактуючих корів по різному вплинули на їх відтворні функиіі. На одне плідне осіменіння кожної корови в 1-й контрольній групі знадобилось провести 2,8 запліднень, у 2-й, 3-й, 4-й $і$ 5-й дослідних групах - по 2,1; 1,9; 1,7 і 2,3 запліднення, що складає відповідно до контролю 75,0; 67,9; 60,7 і 82,1 \%. Нижчі рівні Цинку, Мангану й Кобальту приводили до позитивної динаміки у фізіологічному стані корів, стимулювали їх охоту та забезпечували нормальні умови для протікання процесів запліднення й розвитку зародку у корів. Найкраший вплив на молочну продуктивність корів та їх відтворні функиії мали такі рівні мікроелементів в 1 кг СР кормосуміші, мг: Цинку - 30; Мангану - 30; Кобальту - 0,38; Селену 0,3; Купруму - 9 і Йоду - 0,7. Така концентрація мікроелементів досягалася за рахунок їх зміманолігандних комплексів, а Купруму - його сульфату, Йоду - йодиту калію, а Селену - Суплексу селену.

Ключові слова: високопродуктивні корови, молочна продуктивність, відтворювальна функиія, мікроелементи, змішанолігадний комплекс.

\section{Ветуп}

Важливим показником рентабельності молочного скотарства є тривалість господарського використання маточного поголів'я корів, яке прямо впливає на одержання результату по створенню високопродуктивного стада. Встановлено, що довголітне продуктивне використання молочних корів вважається однією 3 найважливіших ознак, що забезпечує їх високу довічну молочну продуктивність. Тому основною оцінкою високопродуктивних корів $\epsilon$ кількість молока, що одержують за термін їх використання. У зв'язку 3 цим, питанням тривалості господарського використання молочних корів приділяється велика увага як науковцями, так і практиками всіх країн, де розвинене молочне скотарство. Незважаючи на те, що багаторічне продуктивне використання молочних корів $є$ спадково зумовленою й стійкою породною ознакою, в останні роки спостерігається чітка тенденція зниження термінів використання маточного поголів'я корів не тільки в цілому за популяціями, а й в провідних племінних заводах України. Виявилось, що на цю ознаку впливає велика кількість селекційногенетичних та еколого-технологічних факторів. Детальні знання про особливості впливу кожного фактору окремо й в синтезованій комплексній системі дозволяють регулювати тривалість продуктивного використання молочних корів (Lonnerdal, 2000; Lebed'ko, 2007).

Частина мінеральних речовин (Калій, Натрій, Кальцій, Магній, Фосфор, Сульфурум та ін.) використовується на будову основних речовин тіла - білків, жирів і вуглеводів та $є$ постійними компонентами протоплазми живих клітин. Ферум, Купрум, Цинк, Манган, Кобальт, Йод та ін. належать до біоактиваторів, “регуляторів" життя - ферментів, гормонів, вітамінів $\left(\mathrm{B}_{12}\right)$. Дефіцит мінеральних речовин, як і вітамінів, знижує загальне споживання кормів та використання тваринами кормового протеїну (Dmitrochenko \& Moroz, 1971; Hennig, 1976; Mahan, 1990; Bomko et al., 2018).
Нестача Цинку в організмі тварин насамперед знижує синтез білку, у результаті чого пригнічується ріст, знижується плодючість самок і самців. Дефіцит Мангану в раціонах молочних корів призводить до порушення процесів синтезу жирних кислот, деформації скелета в корів і новонароджених телят, до паралічів, стерильності тварин та абортів. Нестача Кобальту в раціонах корів призводить до тих же наслідків що й недостатність вітаміну $\mathrm{B}_{12}$, при цьому виникає анемія, часто супроводжується порушеннями статевої функції та знижує опірність організму до інфекцій. Оптимізація раціонів дійних і сухостійних корів, за допомогою Селену в комплексі з вітаміном Е, активізує руменальне бродіння, підвищує перетравність поживних речовин кормів, покращує окисно-відновні реакції в крові тварин, відтворну функцію, підсилює життєздатність і ріст молодняку (Stoljarchuk et al., 2000; Spears et al., 2004; Ibatullin \& Holubiev, 2017; Kulibaba et al., 2017; Kropyvka, \& Bomko, 2017).

Тому метою досліджень було вивчення показників молочної продуктивності і відтворювальної функції за різних доз Цинку, Мангану й Кобальту в 1 кг СР раціонів сухостійних і лактуючих корів в перший період лактації на фоні нормованих мікроелементів Купруму та Йоду й Суплексу селену.

\section{Матеріал і методи досліджень}

Для експериментальних досліджень, які проводили в ТОВ “Терезине” Білоцерківського району Київської області, за принципом аналогів відібрали п’ять груп високопродуктивних корів української чорнорябої молочної породи. Піддослідних корів годували за однаковими раціонами як у підготовчий так і дослідний періоди. Після завершення зрівняльного періоду досліду різниця в годівлі піддослідних корів за групами була відсутня. В основний період досліду у кормосуміш включали премікс зі змішанолігандними комплексами Цинку, Мангану, Кобальту з Суплексом Селену, сульфатом купруму та йодитом калію згідно зі схемою досліду приведеною в таблиці 1. 
Таблиця 1

Схема науково-господарського досліду, $\mathrm{n}=10$

\begin{tabular}{|c|c|}
\hline Група & Досліджуваний фактор \\
\hline I контрольна & $\begin{array}{l}\text { КС + змішанолігандні комплекси Цинку, Мангану, Кобальту + Суплекс Se й сульфат купруму та } \\
\text { йодит калію. В } 1 \text { кг СР міститься, мг: Цинку - 48; Мангану - 48; Кобальту - 0,68; Селену - 0,3; } \\
\text { Купруму } 9 \text { і Йоду }-0,7\end{array}$ \\
\hline II дослідна & $\begin{array}{l}\text { КС + змішанолігандні комплекси Цинку, Мангану, Кобальту + Суплекс Se й сульфат купруму та } \\
\text { йодит калію. В } 1 \text { кг СР міститься, мг; Цинку - 40; Мангану - 40; Кобальту }-0,58 ; \text { Селену }-0,3 ; \\
\text { Купруму }-9 \text { і Йоду }-0,7\end{array}$ \\
\hline III дослідна & $\begin{array}{l}\text { КС + змішанолігандні комплекси Цинку, Мангану, Кобальту + Суплекс Se й сульфат купруму та } \\
\text { йодит калію. В } 1 \text { кг СР міститься, мг: Цинку - 35; Мангану }-35 \text {; Кобальту }-0,48 ; \text { Селену }-0,3 ; \\
\text { Купруму } 9 \text { і Йоду }-0,7\end{array}$ \\
\hline IV дослідна & $\begin{array}{l}\text { КС + змішанолігандні комплекси Цинку, Мангану, Кобальту + Суплекс Se й сульфат купруму та } \\
\text { йодит калію. В } 1 \text { кг СР міститься, мг: Цинку - 30; Мангану - 30; Кобальту - 0,38; Селену - 0,3; } \\
\text { Купруму } 9 \text { і Йоду }-0,7\end{array}$ \\
\hline V дослідна & $\begin{array}{l}\text { КС + змішанолігандні комплекси Цинку, Мангану, Кобальту + Суплекс Se й сульфат купруму та } \\
\text { йодит калію. В } 1 \text { кг СР міститься, мг: Цинку }-25 \text {; Мангану }-25 \text {; Кобальту }-0,28 ; \text { Селену }-0,3 \text {; } \\
\text { Купруму }-9 \text { і Йоду }-0,7\end{array}$ \\
\hline
\end{tabular}

\section{Результати та їх обговорення}

Для більш глибокої оцінки впливу різних рівнів змішанолігандних комплексів Цинку, Мангану й Кобальту на організм сухостійних корів, провели оцінку їх молочної продуктивності за перші 100 днів лактації. У годівлі піддослідних корів продовжували використовувати кормосуміш, але по мірі збільшення середньодобових надоїв молока збільшували даванку комбікорму. У середньому в кормосуміші за 100 днів лактації знаходилося 12,5 кг комбікорму. Молочна продуктивність піддослідних корів за перші 100 днів лактації наведена в таблиці 2.

\section{Таблиця 2}

Молочна продуктивність піддослідних корів $(\mathrm{n}=10, \mathrm{M} \pm \mathrm{m})$

\begin{tabular}{|c|c|c|c|c|c|}
\hline \multirow{3}{*}{ Показники } & \multicolumn{5}{|c|}{ Групи тварин } \\
\hline & \multirow{2}{*}{$\frac{\text { контрольна }}{1}$} & \multicolumn{4}{|c|}{ дослідні } \\
\hline & & 2 & 3 & 4 & 5 \\
\hline $\begin{array}{l}\text { Надій молока на } 1 \text { корову за } 100 \text { днів } \\
\text { лактації, кг }\end{array}$ & 4020 & 4230 & 4210 & 4270 & 4140 \\
\hline $\begin{array}{l}\text { Середньодобовий } \quad \text { надій } \quad \text { молока } \\
\text { натуральної жирності, кг }\end{array}$ & 40,2 & 42,3 & 42,1 & 42,7 & 41,4 \\
\hline Вміст жиру в молоці, \% & 3,53 & 3,54 & 3,58 & 3,55 & 3,54 \\
\hline $\begin{array}{l}\text { Надій молока } 4 \text { \%-ї жирності на } 1 \\
\text { корову, кг }\end{array}$ & $3547,6 \pm 23,87$ & $\begin{array}{c}3743,6 \pm 42,95 \\
* *\end{array}$ & $\begin{array}{l}3768,0 \pm 31,39 \\
* * *\end{array}$ & $\begin{array}{c}3789,6 \pm 19,82 \\
* * *\end{array}$ & $\begin{array}{c}3663,9 \pm 35,34 \\
*\end{array}$ \\
\hline \pm до контролю, кг & - & $+195,9$ & $+220,4$ & $+242,0$ & $+116,3$ \\
\hline $\begin{array}{l}\text { Середньодобовий надій молока } 4 \text { \%-ї } \\
\text { жирності, кг }\end{array}$ & 35,48 & 37,44 & 37,68 & 37,90 & 36,64 \\
\hline \pm до контролю, кг & - & $+1,96$ & $+2,20$ & $+2,42$ & $+1,16$ \\
\hline У \% до контролю & 100,00 & 105,52 & 106,20 & 106,82 & 103,27 \\
\hline Вміст білка в молоці, \% & 3,23 & 3,25 & 3,25 & 3,26 & 3,22 \\
\hline $\begin{array}{l}\text { Витрати кормів на } 1 \text { корову за дослід, } \\
\text { к. од. }\end{array}$ & 3230 & 3480 & 3490 & 3520 & 3450 \\
\hline Витрати кормів на 1 кг молока, к. од. & 0,83 & 0,82 & 0,83 & 0,82 & 0,83 \\
\hline У \% до контролю & 100,0 & 98,8 & 100,0 & 98,8 & 100,0 \\
\hline
\end{tabular}

Примітка: ***-P $<0,001 ; * *-\mathrm{P}<0,01 ; *-\mathrm{P}<0,05$

Як свідчать дані таблиці 2, ліквідація дефіциту Цинку, Мангану й Кобальту в раціонах корів у сухостійний період за рахунок різних рівнів їх змішанолігандних комплексів позитивно вплинула на подальшу молочну продуктивність.

Від кожної корови контрольної групи за 100 днів лактації отримано 4020 кг натурального молока, а від корів 2-5-ї дослідних груп на 120-250 кг більше при одночасному збільшенні в молоці вмісту на 0,01$0,05 \%$ жиру. У перерахунку валового надою натурального молока на молоко 4 \%-ї жирності різниця за цим показником між коровами 2-ї дослідної групи й контролем склала 195,9 кг, або 5,52\% $(\mathrm{P}<0,01), \quad 3-\ddot{1}$ дослідної - 220,4 кг, або 6,21\% $(\mathrm{P}<0,001)$, 4-ї дослідної - 242,0 кг, або 6,82\% $(\mathrm{P}<0,001)$ і 5-ї дослідної групи й контролем 116,3 кг, або 3,28\%.

У молоці корів дослідних груп, за винятком 5-ї, порівняно 3 контролем, хоча і не надто помітно, але однозначно зростав вміст білка до 3,25-3,26 \% проти $3,23 \%$ у контролі.

Витрати кормів на 1 кг молока в піддослідних корів були практично однакові й коливались від 0,82 до 0,83 к.од. 
Отже, за даними молочної продуктивності корів за перші 100 днів лактації можна судити про позитивну післядію менших рівнів змішанолігандних комплексів Цинку, Мангану й Кобальту в сухостійний період і в період лактації на організм тварин.
Використання різних рівнів змішанолігандних комплексів Цинку, Мангану й Кобальту в раціонах сухостійних i лактуючих корів вплинуло на їх відтворювальні здатності (табл. 3).

Таблиця 3

Показники відтворення корів і якість приплоду, $(\mathrm{M} \pm \mathrm{m} ; \mathrm{n}=10)$

\begin{tabular}{|c|c|c|c|c|c|}
\hline \multirow{3}{*}{ Показники } & \multicolumn{5}{|c|}{ Групи тварин } \\
\hline & \multirow{2}{*}{$\begin{array}{c}\text { контрольна } \\
1 \\
\end{array}$} & \multicolumn{4}{|c|}{ дослідні } \\
\hline & & 2 & 3 & 4 & 5 \\
\hline Тривалість сервіс-періоду, днів & 99,5 & 83,4 & 75,8 & 78,5 & 88,7 \\
\hline 土 до контролю: днів & - & $-16,1$ & $-23,7$ & $-21,0$ & $-10,8$ \\
\hline 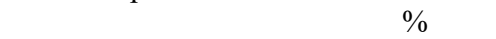 & 100,00 & 83,82 & 76,18 & 78,89 & 89,15 \\
\hline Кількість запліднень на одну голову & $2,8 \pm 0,36$ & $2,1 \pm 0,30$ & $1,9 \pm 0,30$ & $1,7 \pm 0,26$ & $2,3 \pm 0,36$ \\
\hline \pm до контролю & - & $-0,7$ & $-0,9$ & $-1,1$ & $-0,5$ \\
\hline у \% до контролю & 100,0 & 75,0 & 67,9 & 60,7 & 82,1 \\
\hline
\end{tabular}

3 даних таблиці 3 видно, що згодовування різних рівнів змішанолігандних комплексів Цинку, Мангану й Кобальту в 1 кг СР кормосуміші піддослідним коровам протягом всього періоду тільності зумовило те, що на одне плідне осіменіння кожної корови в 1-й контрольній групі знадобилось провести 2,8 запліднень, у 2-й, 3-й, 4-й і 5-й дослідних групах - по 2,1; 1,$9 ; 1,7$ і 2,3 запліднення, що складає відповідно до контролю 75,0; 67,9; 60,7 і 82,1%. Від кількості запліднень залежала й тривалість сервіс-періоду. Так, у корів 1-ї контрольної групи сервіс-період склав у середньому 99,5 днів, у 2-й - 83,4, у 3-й - 75,8, у 4-й 78,5 і в 5-й -88,7 днів, що у відсотковому відношенні склало відповідно 100, 00 \%, 83,82, 76,18, 78,89 і $89,15 \%$.

Таким чином, нижчі рівні Цинку, Мангану й Кобальту за рахунок їх змішанолігандних комплексів позитивно вплинули на фізіологічний стан корів, стимуляцію їх охоти та забезпечили нормальні умови для процесів запліднення й розвитку зародку в корів.

\section{Висновки}

Найкращий вплив на молочну продуктивність корів та їх відтворні функції мали такі рівні мікроелементів в 1 кг СР кормосуміші за рахунок їх змішанолігандних комплексів: Цинку - 30 мг, Мангану - 30 мг і Кобальту - 0,38 мг.

Перспективи подальших досліджень. Подальші дослідження будуть пов'язані 3 вивченням впливу різних рівнів змішанолігандних комплексів Цинку, Мангану і Кобальту на молочну продуктивність корів української чорно-рябої молочної породи в наступні періоди лактації.

\section{References}

Bomko, V. S., Kropivka, Ju. G., \& Bomko, L. G. (2018). Obmin Cynku u visokoproduktyvnyh koriv za zgodovuvannja zmishano-ligandnyh kompleksiv Cynku, Manganu i Kobal'tu. Biologija tvaryn, 20(2), 15-23. doi: 10.15407/animbiol20.02.015 (in Ukrainian).
Dmitrochenko, A. P., \& Moroz Z. M. (1971). Rol' mineral'nyh veshhestv i vitaminov $\mathrm{v}$ ispol'zovanii proteina. Kormlenie sel'skohozjajstvennyh zhivotnyh: sbornik nauchnyh trudov. L.: Kolos, 9, 91-97 (in Russian).

Hennig, A. (1976). Mineral'nye veshhestva, vitaminy, biostimuljatory $\mathrm{v}$ kormlenii sel'skohozjajstvennyh zhivotnyh. Perevod s nemeckogo pod redakciej A. L. Paduchevoj, Ju. I. Raeckoj. M.: Kolos (in Russian).

Ibatullin, I. I., \& Holubiev, M. I. (2017). Effect of feeds containing different sources of manganese on certain carcass parameters of quail. Scientific Messenger of Lviv National University of Veterinary Medicine and Biotechnologies, 19(79), 13-16. doi: 10.15421/nvlvet7903 (in Ukrainian).

Kropyvka, Y., \& Bomko, V. (2017). Efektivnist' vykorystannja premiksiv na osnovi metalohelativ $\mathrm{u}$ godivli koriv v pershi 100 dniv laktacij. NV LNU veterynarnoj medycyny ta biotehnologij. Serija: Sil's'kogospodars'ki nauky, 19(79), 154-158. URL: https://nvlvet.com.ua/index.php/agriculture/article/vie w/2799 (in Ukrainian).

Kulibaba, S. V., Dolgaya, M. M., \& Ionov, I. A. (2017). Effect of feeding chelate complexes of trace elements on the average daily balance of $\mathrm{Cu}, \mathrm{Zn}$ and $\mathrm{Mn}$ in the organism of cows during the period of lactation. Scientific Messenger of Lviv National University of Veterinary Medicine and Biotechnologies, 19(79), 58-61. doi: 10.15421/nvlvet7912 (in Ukrainian).

Lebed'ko, E. Ja. (2007). Hozjajstvennoe ispol'zovanie molochnyh korov $\mathrm{v}$ zavisimosti ot vlijanija rjada faktorov. Vestnik Altajskogo gosudarstvennogo agrarnogo universiteta, 5(31), 47-49 (in Russian).

Lonnerdal, B. (2000). Dietary factors influencing zinc absorbtion. J. Nutr., 130(5), 1378-1383. doi: $10.1093 / \mathrm{jn} / 130.5 .1378 \mathrm{~S}$.

Mahan, D. C. (1990). Mineral nutrition of the cow: a review. J. Anim. Sci., 68(2), 573-582. doi: $10.2527 / 1990.682573 x$.

Spears, J. W., Schlegel, P. A., Seal, M. C., \& Lloyd, K. E. (2004). Bioavailability of zinc from zinc sulfate and different organic zinc sources and their effects on ruminal volatile fatty acid proportions. Livestock 
Production Science, 90(2/3), 211-217. opasovyshhnyj period. Sil's'kyj gospodar, 7-8, 20-21. doi: 10.1016/j.livprodsci.2004.05.001.

(in Ukrainian).

Stoljarchuk, P. Z., Petryshak, R. A. \& Naumjuk, O. S.

(2000). Racional'na godivlja dijnyh koriv u litn'- 